\title{
Upper Frasnian and lower Famennian (Upper Devonian) conodonts of the Compte section (Spanish Central Pyrenees)
}

\author{
Conodontos del Frasniense superior y Fameniense inferior (Devónico Superior) de la sección Compte \\ (Pirineo Central Español)
}

Gonçalo G. SILVÉRIO (1) , José I. VALENZUELA-RÍOS@ \& Jau-Chyn LIAO @

\begin{abstract}
Through the study of conodonts, strata around the Frasnian-Famennian boundary in the Compte section were analyzed in detail. Twenty-four samples in a $12 \mathrm{~m}$ thick sequence yielded 13 species of conodonts belonging to Ancyrodella, Ancyrognathus, Icriodus, Palmatolepis, and Polygnathus. Besides conodonts, other groups such as foraminifers, radiolarians, brachiopods, ostracods and crinoids were also found in the sequence. The conodont record, shows the FZ13, from the uppermost Frasnian, and the minuta and crepida zones from the lower Famennian. The last Frasnian fossil was obtained from Bed 92b and the first Famennian fossil was from Bed 92d, which are separated by about $45 \mathrm{~cm}$. Thus, between these two samples, the lowest three Famennian conodont zones have to be represented or missing. The absence of any stratigraphic hiatus between these levels suggests that extreme condensation took place in the early Famennian in the CP section.
\end{abstract}

Resumen: Mediante el estudio de conodontos, se analizan en detalle los estratos en las proximidades del límite Frasniense-Fameniense en la sección Compte. En los $12 \mathrm{~m}$ estudiados se tomaron 24 muestras que han proporcionado 13 especies de conodontos pertenecientes a Ancyrodella, Ancyrognathus, Icriodus, Palmatolepis y Polygnathus. Además de los conodontos, se han registrado otros grupos de microfósiles como foraminíferos, radiolarios, braquiópodos, ostrácodos y crinoideos. El registro de conodontos indica la presencia de la FZ13, del Frasniense terminal, y las Zonas minuta y crepida, del Fameniense inferior. La última muestra con conodontos frasnienses es la CP/92b y la primera con conodontos famenienses las CP/92d. Ambas nuestras están separadas por unos $45 \mathrm{~cm}$. Por tanto, entre ambas muestras se deben de situar las tres primeras zonas de conodontos del Fameniense, o están ausentes. Dado que no se ha observado ningún hiato estratigráfico en esta parte de la sección, se interpreta una condensación extraordinaria en el comienzo del Fameniense en la sección CP.
Received: 10 August 2021

Accepted: 16 November 2021

Published online: 03 December 2021

Corresponding author:

Gonçalo G. Silvério

gsilverio@uevora.pt

Keywords:

Frasnian

Famennian

Conodonts

Biostratigraphy

Pyrenees

Palabras-clave:

Frasniense

Fameniense

Conodontos

Bioestratigrafía

Pirineos

\section{INTRODUCTION}

The complex evolution of the Devonian sedimentation in the Pyrenees makes it difficult to establish a synthetic stratigraphic column. After more than 40 years of geological research in the Paleozoic of the Pyrenees, Mey (1967) introduced the concept of Main faciesareas in the stratigraphy of the Pyrenean Devonian rocks. He recognized four major facies-areas (see also Valenzuela-Ríos \& Liao, 2006 for a summary), which can be further subdivided into sub-facies-areas. Our research is centered in the Southern Facies-area, in the Compte sub-facies area of Mey (op.cit.).

Ziegler (1959) reported Devonian conodonts from the Compte subfacies-area in the Compte section. Later, Boersma (1973), confirmed the presence of Givetian to Lower Carboniferous rocks based on a biostratigraphic analysis using conodonts. Subsequently, the sampling program developed by Valenzuela-Ríos and his team has demonstrated the international relevance of this section for the Lower, Middle and lower Upper Devonian: Valenzuela-Ríos et al. (2005, 2015, 2017), Valenzuela-Ríos and Liao (2012), Liao (2014), Liao and Valenzuela-Ríos (2008, 2017), Martínez-Pérez (2010a, 2010b), Martínez-Pérez et al. (2011), Martínez-Pérez and Valenzuela-Ríos (2014), Gouwy et al. (2016) and Slavík et al. (2016).

The compiled bio-chronostratigraphic succession is composed of two sections (Valenzuela-Ríos et al., 2005, 2017): the Compte-I (CP-I) section, corresponding to the Lower Devonian sequence; and the Compte (CP) section, corresponding to the Middle and Upper

(c) The Author(s) 2021. This is an open-access article distributed under the terms of the Creative Commons Attribution 4.0 International License (for details please see http://creativecommons.org/licenses/by/4.0/), which permits use, copy, adaptation, distribution, and reproduction in any medium or format, as long as you give appropriate credit to the original author(s) and the source. 
Devonian sequence. Liao and Valenzuela-Ríos (2017) summarized previous works on the detailed conodont bio-chronostratigraphy for the Givetian and early Frasnian and pointed to the critical interval of the Frasnian-Famennian transition: between Bed 82 (Frasnian) and Bed 89 (Famennian) (Liao \& ValenzuelaRíos, 2017, p. 103, fig. 3).

The main goal of this work is to make a detailed biostratigraphical conodont study across the FrasnianFamennian (Upper Devonian) transition in the CP section.

\section{GEOLOGICAL SETTING}

The CP section is located in the central part of the Pyrenees, on a road cut, at about $1,5 \mathrm{~km}$ north of Gerri de la Sal (Lérida, Spain) (Fig. 1).

The Pyrenean mountain range is the result of the Alpine Orogeny, in which some of the hercynian thrusts were reactivated and new thrusts were generated (Muñoz,
1992). The last thrusts all merge towards the south and many have an intensified vertical displacement from interaction with the Triassic evaporites, which propelled them upwards and gave rise to plunging browfolds ("tête plongeante" style deformation; Muñoz, 1992).

The Compte sections outcrop in one of the plunging browfolds, constituted solely by an inverted DevonianCarboniferous sequence (Fig. 1). The CP section comprises the Comabella, La Mena and Barousse formations, which roughly correspond to members A, B and $\mathrm{C}$ of the Compte Formation (Boersma, 1973; Liao \& Valenzuela-Ríos, 2017), respectively:

- Comabella Formation (Dccc; Givetian to Famennian, in the studied area), composed of nodular and bedded limestones of pink, red, blue and green colors.

- La Mena Formation (Dccm; Famennian), composed of red nodular and marly limestones.

- Barousse Formation (Dccb; Famennian-Carboniferous), composed of thick nodular limestone beds of grey color.
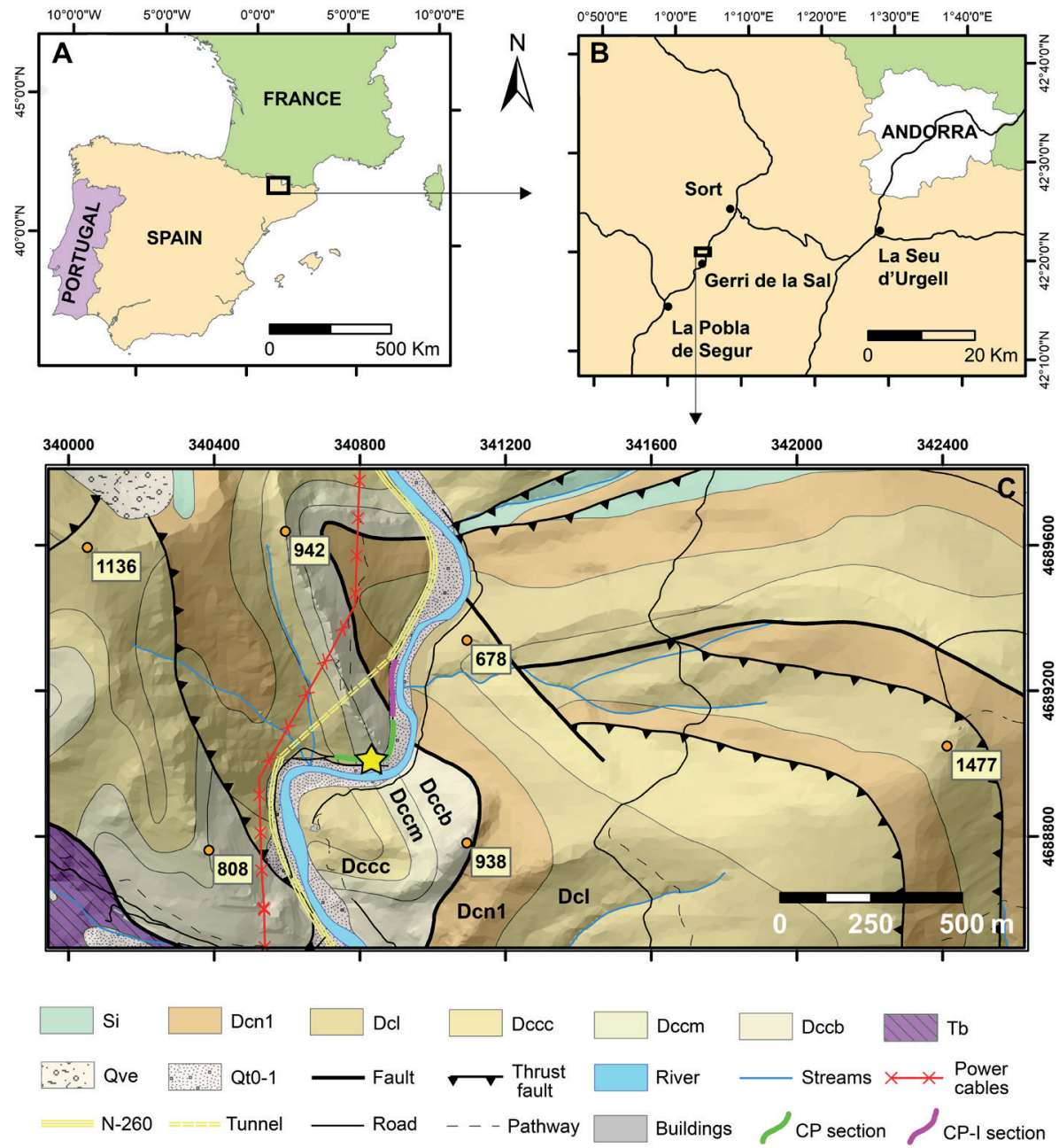

Figure 1. Geographical and geological setting of the Compte sections (CP and CP-1). A, Location within Spain; B, Major cities and roads close to the studied site; C, Detailed geological map of El Compte (adapted from Institut Cartogràfic i Geològic de Catalunya, 2021). Yellow star indicates the studied site. Si, Silurian, undifferentiated; Dcn1, Rueda Formation (Lower Devonian); Dcl, Villec Formation (Lower Devonian); Dccc, Comabella Formation (Emsian to Famennian); Dccm, La Mena Formation (Upper Devonian); Dccb, Barousse Formation (Famennian-Carboniferous); Tb, Buntsandstein Facies (Lower-Middle Triassic); Qve, Holocene conglomerates; Qt0-1, Holocene alluvial deposits. Coordinate system used: ETRS 1989 UTM Zone 31N. 


\section{MATERIALS AND METHODS}

The analyzed sequence, which corresponds to the upper part of the Comabella Formation (Fig. 2), is composed of a $12 \mathrm{~m}$ succession of grey to red nodular limestones, with thin interbedded layers of marly limestone. The thickness of the layers varies significantly, but tends to be thinner in the marly levels and thicker in the pure nodular limestones. The marly limestone in layer 91a, which has a thickness varying between 10 to $14 \mathrm{~cm}$, is lens-shaped and developed in a marly matrix (Fig. 2). This sequence is between Beds 84-90 of Liao and Valenzuela-Ríos (2017, fig. 3), which corresponds respectively to Bed 84 and above Bed 97 herein (Fig. 3).

The samples were taken from each level (with the exception of levels 83 and 88), making a total of 24 samples, with each one weighting between 0.7 and 3 $\mathrm{kg}$ (Tab. 1). They were processed using formic acid $(\approx$ $8 \%)$ in 5-10 L solutions, while suspended with the use of nets.

The residue was separated by density through decantation, dried at a temperature no higher than $40^{\circ} \mathrm{C}$, and then sorted manually using a Leica WILD M3B microscope. Once the residues were sorted, the selected fossils were photographed with the use of a Scanning Electron Microscope (model HITACHI S4800) hosted at the University of Valencia. Digital images were then selected and rearranged for the conodont plate (Fig. 4).

All figured specimens are stored in the Museo de Historia Natural de la Universidad de Valencia (MVHN-UV), in Burjassot (Valencia, Spain), with references MGUV 5410 to MGUV 5422.

\section{SYSTEMATIC PALEONTOLOGY}

Phylum CHORDATA Haeckel, 1874

Subphylum VERTEBRATA Lamarck, 1802

Class CONODONTA Pander, 1856

Suborder OZARKODININA Dzik, 1976

Family SPATHOGNATHODONTIDAE Hass, 1959

Genus Ancyrodella Ulrich \& Bassler, 1926

Type-species. Ancyrodella nodosa Ulrich \& Bassler, 1926. Frasnian; Europe, Asia, Australia, North America.

Ancyrodella curvata (Branson \& Mehl, 1934)

Figure 4A

1934 Ancyrognathus curvata n. sp.; Branson \& Mehl, p. 241, PI. 19, figs. 6, 11.

1985 Ancyrodella curvata; Ziegler \& Wang, PI. 4, fig. 1. 1992 Ancyrodella curvata; Matyja \& Narkiewicz, PI. 1, figs. 4-6, PI. 4, figs. 12, 16.

1993 Ancyrodella curvata; Ji \& Ziegler, p. 51-52, PI. 2, figs. $4-5$.

Table 1. Stratigraphic distribution and number of conodonts in the analyzed CP sequence with indication of the sample codes and weights. Ag., Ancyrognathus; Ad., Ancyrodella; I., Icriodus; Pa., Palmatolepis; Po., Polygnathus. The nomenclatorial system used refers to the section (CP) followed by bed number and then the indication of the position within the bed; i.e., $\mathrm{CP} / 84 / 17-25$ means sample taken in the interval between 17-25 cm above the base of Bed 84 . An exception was made for samples CP/92b/140-160 and CP/92c/0-9, which were taken from beds $92 a$ and $92 b$, respectively. When no indication is given, the sample was taken in the whole bed. If a letter " $T$ " is present at the end, then the sample was measured from the top down.

\begin{tabular}{|c|c|c|c|c|c|c|c|c|c|c|c|c|c|c|c|c|c|c|c|c|c|c|c|c|}
\hline Stage & \multicolumn{16}{|c|}{ Frasnian } & \multicolumn{8}{|c|}{ Famennian } \\
\hline Biozonation & \multicolumn{16}{|c|}{ FZ13 } & \multicolumn{4}{|c|}{ minuta } & \multicolumn{4}{|c|}{ crepida } \\
\hline Sample name & $\begin{array}{l}\stackrel{2}{N} \\
\frac{1}{N} \\
\frac{1}{5} \\
\frac{0}{0} \\
0\end{array}$ & $\begin{array}{l}\frac{0}{10} \\
\infty \\
\frac{\infty}{0}\end{array}$ & $\begin{array}{l}\frac{N}{1} \\
\frac{0}{0} \\
\frac{0}{0} \\
0\end{array}$ & 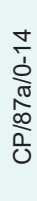 & 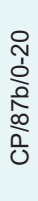 & 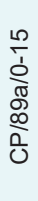 & 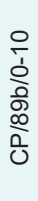 & 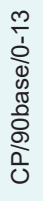 & $\begin{array}{l}\frac{5}{50} \\
\text { on } \\
\frac{0}{0} \\
\frac{0}{0} \\
0\end{array}$ & 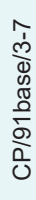 & 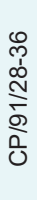 & 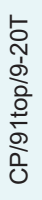 & 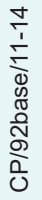 & $\begin{array}{l}\infty \\
\infty \\
\infty \\
\stackrel{N}{N} \\
\stackrel{N}{\mathbb{N}} \\
\text { N } \\
\frac{0}{0} \\
0\end{array}$ & 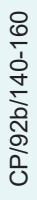 & 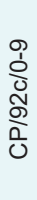 & $\begin{array}{l}\text { ণ্ } \\
\frac{\text { Dे }}{0}\end{array}$ & $\frac{\frac{5}{\infty}}{\frac{0}{o}}$ & 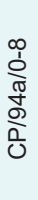 & $\begin{array}{l}\text { o } \\
\text { o. } \\
\text { o } \\
\text { o } \\
\frac{1}{0} \\
0\end{array}$ & $\frac{0}{\frac{0}{0}}$ & $\begin{array}{l}0 \\
0 \\
0 \\
0 \\
\frac{0}{0} \\
\frac{0}{0} \\
0\end{array}$ & 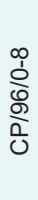 & 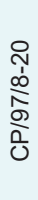 \\
\hline Sample weight (kg) & N̦ & $\tilde{\sim}$ & $\stackrel{\circ}{\circ}$ & $\check{F}$ & $\stackrel{\sim}{\sim}$ & $\stackrel{\circ}{\circ}$ & $\stackrel{\circ}{\sim}$ & $\stackrel{\sim}{r}$ & $\stackrel{\infty}{\sim}$ & 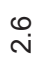 & ウ & $\stackrel{\sim}{\sim}$ & $\stackrel{\sim}{r}$ & 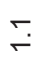 & ণั & مֶ & $\stackrel{\infty}{0}$ & $\check{\sim}$ & $\stackrel{\text { m}}{\sim}$ & $\hat{0}$ & $\stackrel{\infty}{0}$ & $\stackrel{\infty}{\sim}$ & $\stackrel{\sim}{\sim}$ & $\stackrel{\infty}{0}$ \\
\hline Ag. sinelaminus & & & & & & & & & & & & & & & & & & & & 2 & & & & \\
\hline Pa. crepida & & & & & & & & & & & & & & & & & & & 1 & 2 & 1 & & 1 & 1 \\
\hline Pa. cf. subperlobata & & & & & & & & & & & & & & & & & & 1 & & & & & & \\
\hline Po. cf. eoglaber & & & & & & & & & & & & & & & & & 1 & & & & & & & \\
\hline Pa. lobicornis & & & & & & & & & & & & & & & & & 1 & 3 & 2 & 1 & 2 & 3 & 1 & 1 \\
\hline Ag. amana & & & & & & & & & & & & & & 1 & & & & & & & & & & \\
\hline Po. webbi & & & & & & & & & & & 1 & & & 1 & & 2 & & & & & & & & \\
\hline Ag. asymmetricus & & 1 & 2 & & & & 1 & & & 1 & 1 & & & 2 & & & & & & & & & & \\
\hline I. cf. (alternatus) alternatus & 1 & & & & & & & & & & & & 2 & 2 & 1 & 3 & 1 & 4 & 3 & & & & & \\
\hline Pa. winchelli & 2 & 3 & 1 & 1 & 1 & & 6 & 2 & & & 1 & & & & & 1 & & & & & & & & \\
\hline Pa. boogaardi & 1 & & & & & & & 1 & 1 & 3 & 1 & 1 & 2 & 3 & 1 & 1 & & & & & & & & \\
\hline Ad. curvata "late form" & 1 & 1 & 1 & 1 & & & 1 & 2 & & 1 & 1 & & 1 & 3 & 1 & & & & & & & & & \\
\hline Pa. bogartensis & 1 & 1 & & 1 & & & & 1 & & & 1 & & & & 1 & & & & & & & & & \\
\hline
\end{tabular}




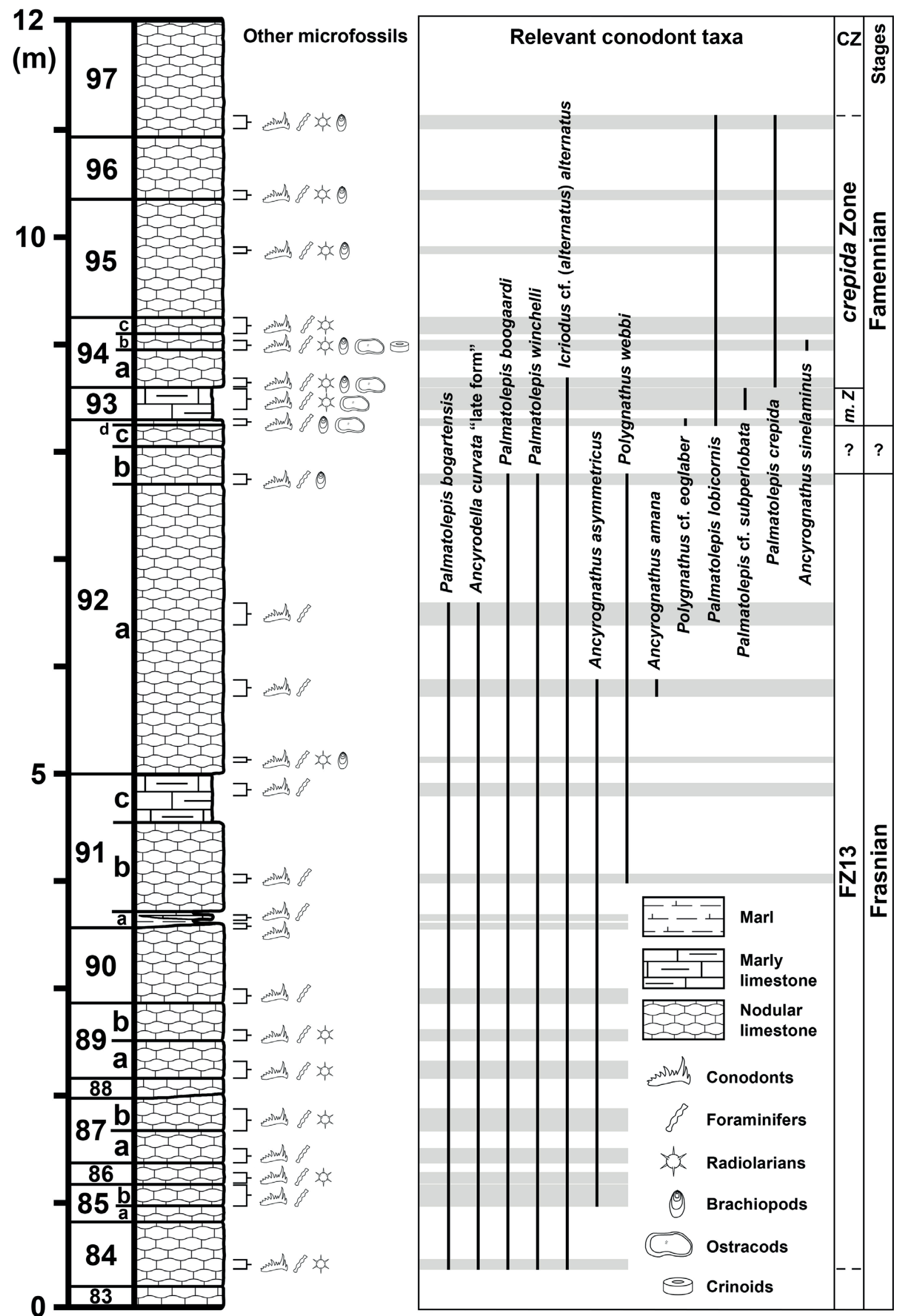

Figure 2. Stratigraphical column of the analyzed sequence, with the identification of the layers, samples and microfossils found in each sample, as well as the stratigraphical distribution of each identified conodont species and respective biozones. CZ, Conodont Zones; m. Z., minuta minuta Zone. 
2015 Ancyrodella curvata; Mahboubi \& Gatovsky, fig. $3 \mathrm{D}, 3 \mathrm{E}$.

Material. 14 specimens of Ancyrodella curvata "late" form, from samples CP/84 (1), CP/85b (1), CP/86 (1), $\mathrm{CP} / 87 \mathrm{a}(1), \mathrm{CP} / 89 \mathrm{~b}(1), \mathrm{CP} / 90$ base (2), CP/91base (1), CP/91 (1), CP/92base (1), CP/92a/73-88 (3) and $\mathrm{CP} / 92 \mathrm{~b} / 140-160(1)$.

Description. $\mathrm{P}_{1}$ element asymmetrical relative to the carina and curved inwards. Free blade corresponding to about $1 / 2$ of the length. The outer lobe is parallel to the carina, while the inner one is directed lateroanteriorly. Both lobes have well-developed secondary carinas. An accessory carina is present on the outer lobe, being projected postero-laterally and ornamented by ridges of nodes. The main carina, secondary carinas and accessory carina all have a correspondent, welldeveloped, keel. The basal pit is small, rhombic and located at about mid-length of the platform.

Discussion. This species is characterized by having a well-developed accessory lobe, with respectively welldeveloped carina and keels. Specimens of its closest relative, Ancyrodella lobata Branson \& Mehl (1934), only develop a small protrusion on the outer-posterior side, without ever being individualized as an accessory lobe. The outer margin of Ancyrodella curvata is clearly concave, while in Ancyrodella lobata the outer margin is usually straight.

Specimens of Ancyrodella curvata can be differentiated into an "early" form and a "late" form (Klapper, 1989). The "early" form have a poorly-developed accessory lobe, while the "late" form have a well-developed accessory lobe.

Age range. Upper Devonian (Frasnian); of Ancyrodella curvata "early" form: punctata-Lower rhenana zones (Klapper, 1989) = FZ5-FZ11 (Klapper \& Kirchgasser,

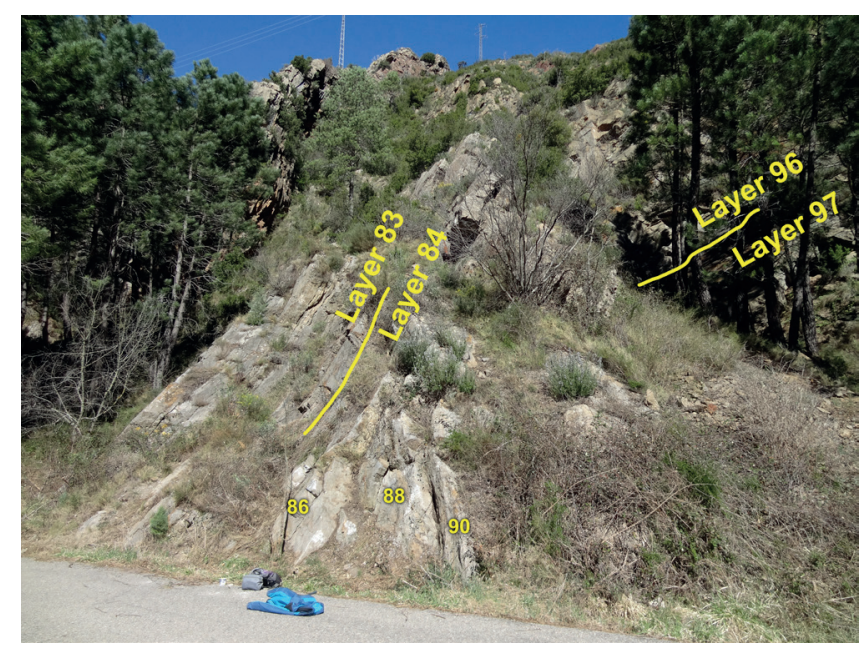

Figure 3. General view of the studied section, indicating the base (layer 83) and top (layer 97). The difference in attitude of the layers is due to perspective, not from deformation.
2016); of Ancyrodella curvata "late" form: Upper hassi-linguiformis zones (Klapper, 1989) $=$ FZ9-FZ13 (Klapper \& Kirchgasser, 2016).

\section{Genus Ancyrognathus Branson \& Mehl, 1934}

Type-species. Ancyrognathus symmetricus Branson \& Mehl, 1934. Famennian; Asia, North America.

\section{Ancyrognathus amana Müller \& Müller, 1957}

Figure 4C

1957 Ancyrognathus amana n. sp.; Müller \& Müller, p. 1095, PI.138, fig. 5.

1990 Ancyrognathus amana; Klapper, p. 1001-1003, figs. 2.1-2.6.

Material. 1 specimen from sample CP/92a/73-88.

Description. $\mathrm{P}_{1}$ element with an elliptical outline. Free blade tall, short and corresponding to about $1 / 3$ of the total length. The platform is wider at middle length and diminishes in width on both ends. Both anterior and posterior carinas are prominent, with very welldeveloped adcarinal grooves. The posterior carina, incomplete in the figured specimen, is slightly bent inwards.

The secondary carina makes a right angle with the posterior carina. The basal cavity is not distinguishable in the figured specimen.

Discussion. This species is characterized by the right angle between the posterior and secondary carinas and by the weak ornamentation of the platform. It differs from Ancyrognathus triangularis Youngquist (1945), which has an obtuse angle between the secondary and posterior carinas and the joining of the secondary keel is anterior to the center of the basal pit, while in Ancyrognathus amana that joining is located at the center of the basal pit.

Age range. Upper Devonian (Frasnian); Upper rhenana-linguiformis zones (Klapper, 1990) = FZ12FZ13 (Klapper \& Kirchgasser, 2016).

Ancyrognathus asymmetricus (Ulrich \& Bassler, 1926) Figure 4D

1926 Palmatolepis asymmetrica n. sp.; Ulrich \& Bassler, p. 50, PI. 7, fig. 18.

1990 Ancyrognathus asymmetricus; Klapper, p. 10031005, figs. 4.1-4.16, 5.9-5.16, 6.4, 6.7, 6.10, 7.10-7.13. 1993 Ancyrognathus asymmetricus; Ji \& Ziegler, PI. 3, figs. 3-4.

1995 Ancyrognathus asymmetricus; Matyja \& Narkiewicz, PI. 2, fig. 1.

Material. 8 specimens from samples $\mathrm{CP} / 85 \mathrm{~b}$ (1), CP/86 (2), CP/89b (1), CP/91base (1), CP/91/28-36 (1) and $\mathrm{CP} / 92 \mathrm{a} / 73-88$ (2).

Description. $\mathrm{P}_{1}$ element with a subtriangular shape. The blade is fixed, high, located along the right margin 
of the platform and corresponding to about $1 / 3$ to $1 / 2$ of the total length. The maximum width of the main body is located at the posterior third. The three lobes end in narrow points. The anterior part of the platform is composed of deep throughs, next to the anterior carina. The anterior carina is disposed along the right margin of the platform and deflects inwards in the posterior third. Posterior and secondary carinas form an acute angle. The first is straight and projected posterolaterally, while the second one turns slightly outwards. Shallow adcarinal grooves are present along those two carinas, on both sides. The platform is ornamented by very fine nodes, disposed in two to five rows, parallel to the carinas. The sinus is well-developed in mature specimens. In lateral view, the denticles of the anterior carina are higher and bigger than the ones from the posterior and secondary carinas. Keels are weakly, but completely, developed. Anterior and posterior keels are directly linked, while the secondary keel intersects them in the basal pit. Basal pit small and elongate.

Discussion. This species is characterized by an interrupted anterior carina located on the right side of the platform. It differs from Ancyrognathus calvini Miller \& Youngquist (1947) in the deep trough that separates the anterior carina from the main body and by the lack of a rounded protrusion on the inner margin, anterior to the lateral lobe.

Age range. Upper Devonian (Frasnian); Upper rhenana (Ji \& Ziegler, 1993)-linguiformis zones (Klapper, 1990) = FZ12-FZ13 (Klapper \& Kirchgasser, 2016).

\section{Ancyrognathus sinelaminus Branson \& Mehl, 1934}

Figure 4G

1934 Ancyrognathus sinelamina n. sp.; Branson \& Mehl, p. 248, pl. 20, figs. 20, 22.

2015 Ancyrognathus sinelaminus; Mahboubi \& Gatovsky, fig. 3J.

Material. 2 specimens from sample CP/94b.

Description. $\mathrm{P}_{1}$ element with a very short free blade and platform torqued transversely. Main body ornamented by small nodes, disposed in rows parallel to the carina. Carina composed of slightly taller nodes than the ones that compose the main body. The posterior end is pointed. Basal cavity small and lensoid, located at $1 / 3$ from the posterior end. A high keel is present beneath the carina.

Discussion. The lack of a lateral lobe is the main distinguishable character of this species, but it is not compliant with the diagnosis of the genus Ancyrognathus, as discussed by Klapper (1990). However, the remaining characteristics do not exclude it from the genus.

Age range. Upper Devonian (Famennian); delicatula platys-glabra pectinata zones (Klapper et al., 1981).

Genus Palmatolepis Ulrich \& Bassler, 1926

Type-species. Palmatolepis perlobata Ulrich \& Bassler, 1926. Upper Devonian; Europe and North America.

Palmatolepis bogartensis (Stauffer, 1938)

Figure $4 \mathrm{H}$

1938 Nothognathella bogartensis n. sp.; Stauffer, p. 436, PI. 48, fig. 30.

1993 Palmatolepis bogartensis; Klapper \& Foster, p. 17-18, figs. 13.4-13.16, 19.1-19.5, 20.1-20.11.

2015 Palmatolepis bogartensis; Mahboubi \& Gatovsky, p. 323-324, fig. 4C.

Material. 6 specimens from samples CP/84 (1), CP/85b (1), CP/87a (1), CP/90base (1), CP/91/28-36 (1) and CP/92b/140-160 (1).

Description. Short free blade, corresponding to about $1 / 6$ of the whole length. Platform with a subtriangular shape, inner margin slightly convex and outer lobe welldeveloped, wide and directed laterally. The anterior and posterior contact of the margins of the lobe are smooth. The azygous node is at the posterior $1 / 3$ of the length and located posterior to the lobe. The anterior and posterior carinas make a sinuous shape close to the azygous node. The anterior carina is straight in the anterior $2 / 3$ of its length. The surface of the platform is ornamented by small nodes, disposed randomly.

Discussion. This species differs from Palmatolepis winchelli (Stauffer, 1938) in the smooth contact of the lobe with the outer margin of the platform and in the more developed lobe.

Figure 4. A, Ancyrodella curvata, specimen MGUV 5410, from sample CP/91/28-36; B, Icriodus cf. (alternatus) alternatus, specimen MGUV 5413, from sample CP/92base/11-14; C, Ancyrognathus amana, specimen MGUV 5415, from sample CP/92a/73-88; D, Ancyrognathus asymmetricus, specimen MGUV 5411, from sample CP/91/28-36; E, Palmatolepis boogaardi, specimen MGUV 5414, from sample CP/92base/11-14; F, Polygnathus webbi, specimen MGUV 5417, from sample CP/92c/0-9, 1,2 and 3 refer to oral view, lateral view and aboral view, respectively; G, Ancyrognathus sinelaminus, specimen MGUV 5422, from sample CP/94b/0-9, 1 and 2 refers to oral view and lateral view, respectively; $\mathbf{H}$, Palmatolepis bogartensis, specimen MGUV 5416, from sample CP/92b/140-160; I, Polygnathus cf. eoglaber, specimen MGUV 5418, from sample CP/92d, 1 and 2 refers to oral view and lateral view, respectively; J, Palmatolepis winchelli, specimen MGUV 5412, from sample CP/91/28-36; K, Palmatolepis crepida, specimen MGUV 5421, from sample CP/94a/0-8; L, Palmatolepis lobicornis, specimen MGUV 5419, from sample CP/93/19T; M, Palmatolepis cf. subperlobata, specimen MGUV 5420, from sample CP/93/19T; scale bar = 0.5 mm. 


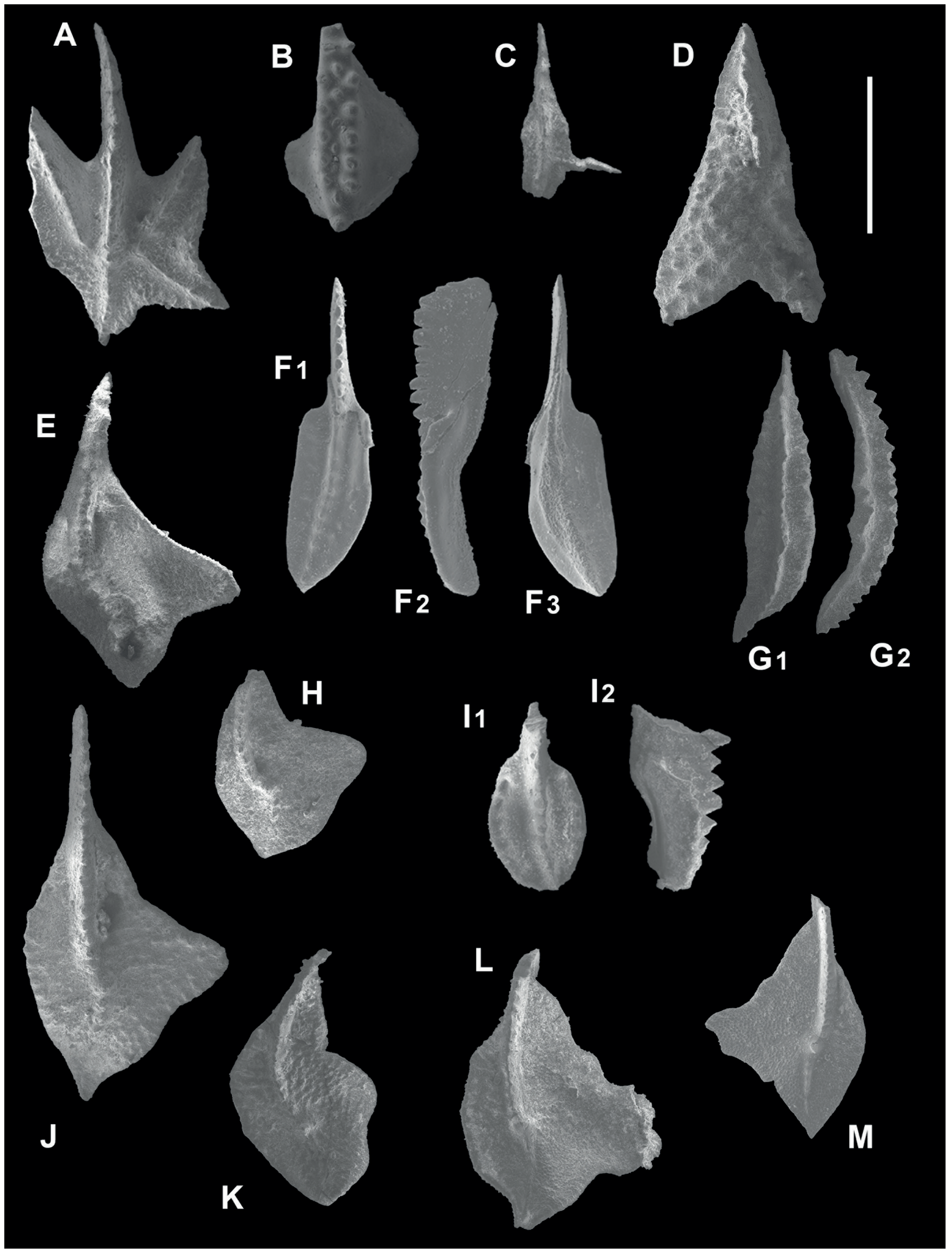


Age range. Upper Devonian (Frasnian); Upper rhenana-linguiformis zones (Klapper \& Foster, 1993) = FZ13 (Klapper \& Kirchgasser, 2016).

\section{Palmatolepis boogaardi Klapper \& Foster, 1993}

Figure 4E

1993 Palmatolepis boogaardi n. sp.; Klapper \& Foster, p. 18-22, figs. 13.3, 14.1-14.10, 17.1, 17.2, 19.13-19.15.

Material. 15 specimens from samples CP/84 (1), CP/90base (1), CP/90top (1), CP/91base (3), CP/91/2836 (1), CP/91top (1), CP/92base (2), CP/92a/73-88 (3), CP/92b/140-160 (1) and CP/92c/0-9 (1).

Description. Short free blade, corresponding to about $1 / 6$ of the whole length. Inner margin of the platform slightly convex. The lobe is well-developed and directed laterally. The posterior side of the inner margin is convex. The anterior and posterior contact of the margins of the lobe are smooth, although the posterior one is slightly more curved. The azygous node is at the posterior $1 / 3$ of the length and located posterior to the lobe. The anterior and posterior carinas make a sinuous shape close to the azygous node. The anterior carina is slightly curved throughout its length. A deep adcarinal groove on the outer side of the platform is present, located on the anterior end. The surface of the platform is ornamented by small nodes, disposed randomly, and by thin and small ridges on the margins.

Discussion. This species is characterized by having a subtriangular outline, a wide outer side of the platform and a well-developed lobe. It differs from Palmatolepis bogartensis in the convex inner margin on the posterior side and in the slender lobe.

Age range. Upper Devonian (Frasnian); linguiformis zone (Klapper \& Foster, 1993) = FZ13 (Klapper \& Kirchgasser, 2016).

\section{Palmatolepis crepida Sannemann, 1955 Figure 4K}

1955 Palmatolepis crepida n. sp.; Sannemann, p. 134, PI. 6, fig. 21.

1985 Palmatolepis crepida; Ziegler \& Wang, PI. 4, figs. 22-23.

1989 Palmatolepis crepida; Wang, PI. 16, fig. 8, PI. 20, figs. 8-9.

1993 Palmatolepis crepida; Matyja, PI. 26, fig. 3.

1993 Palmatolepis crepida; Ji \& Ziegler, p. 59, PI. 22, figs. $1-7$.

1995 Palmatolepis crepida; Matyja \& Narkiewicz, PI. 3, fig. 4.

Material. 6 specimens from samples CP/94a (1), CP/94b (2), CP/94c (1), CP/96 (1) and CP/97 (1).

Description. Free blade absent. Inner margin of the platform slightly convex on the anterior half and straight on the posterior one. The lobe is poorly-developed, directed latero-anteriorly and with a semicircular shape. The inner margin terminates before the outer margin, anteriorly, and is slightly elevated. The anterior and posterior contact of the margins of the lobe are smooth. The posterior end is quadrate. The azygous node is at the posterior $1 / 3$ of the length and located below the lobe. The posterior carina is slightly curved inwards, while the anterior one is slightly curved outwards throughout its length. The surface of the platform is composed of small nodes disposed randomly.

Discussion. This species is characterized by a dropshape platform with a reduced (or absent) lobe. It differs from Palmatolepis perlobata in the lesser elevation of the inner margin in the anterior end and in the presence of a small triangular projection on the posterior side of the outer margin of the platform.

Age range. Upper Devonian (Famennian); crepidarhomboidea zones (Spalletta et al., 2017).

Palmatolepis cf. subperlobata Branson \& Mehl, 1934

Figure 4M

1934 Palmatolepis subperlobata n. sp.; Branson \& Mehl, p. 235 , PI. 18 , figs. 11-12.

1966 Palmatolepis subperlobata; Glenister \& Klapper, p. 822-823, Pl. 92, figs. 5-7.

1994 Palmatolepis subperlobata; Metzger, p. 638-639, figs. 17.2, 17.3, 17.7, 17.9, 17.10.

2004 Palmatolepis subperlobata; Klapper et al., p. 381382, figs. $7.35,7.36$.

Material. One specimen from sample CP/93.

Description. Free blade broken on the identified specimen. Inner margin of the platform convex on the anterior $2 / 3$ and concave on the posterior third. The lobe is well-developed, narrow and directed laterally. The posterior side of the outer margin is slightly concave. The posterior end is pointed. The anterior and posterior contact of the margins of the lobe are smooth. The azygous node is just below middle length of the platform and located below the lobe. The posterior carina is straight, while the anterior one is slightly curved outwards on the posterior third. The surface of the platform is smooth and the inner margin presents small nodes.

Discussion. Typical specimens of $P a$. subperlobata have a slightly curved posterior end and right lobe margins, which this specimen does not have. This species differs from $\mathrm{Pa}$. perlobata in the lack of an elevated inner margin and well-developed lobe.

Age range. Upper Devonian (Famennian); subperlobata-marginifera marginifera zones (Spalletta et al., 2017).

Palmatolepis lobicornis Schülke, 1995

Figure 4L 
1959 Palmatolepis subperlobata; Hass, PI. 50, fig. 8. 1963 Palmatolepis (Panderolepis) subperlobata n. subsp. A; Helms, p. 478, 480, 482, PI. 1, fig. 19, PI. 2, figs. 23, 24, Pl. 3, fig. 10, text-fig. 2.17.

1995 Palmatolepis lobicornis n. sp.; Schülke, p. 40-41, PI. 4, figs. 1-17.

1999 Palmatolepis lobicornis; Schülke, PI. 2, fig. 10. 2004 Palmatolepis lobicornis; Klapper et al., p. 379, fig. 7.30.

2007 Palmatolepis lobicornis; Over, fig. 13.8.

2016 Palmatolepis lobicornis; Huang \& Gong, figs. 6.2, 6.11.

Material. 14 specimens from samples $C P / 92 d(1)$, CP/93 (3), CP/94a (2), CP/94b (1), CP/94c (2), CP/95 (3), CP/96 (1) and CP/97 (1).

Description. Free blade short, corresponding to about $1 / 4$ of the whole length. Platform with an almost subtriangular shape. Inner margin convex and ending posteriorly to the outer margin on the anterior end. The posterior side of the outer margin is convex on the anterior half and concave on the posterior one. The lobe is long, with a regular and high width and directed laterally. A small bulge is present on the anterior margin of the lobe. The anterior and posterior contact of the margins of the lobe are almost sharp, make an obtuse angle with the inner margin and a right angle with the anterior carina. The azygous node is located at middle length of the platform and at the same height as the lobe. The anterior carina is slightly curved outwards while the posterior one is slightly curved inwards. The surface of the platform is smooth on the posterior half and has small nodes on the inner side of the anterior half.

Discussion. This species is characterized by having a smooth platform, a long lobe and a posterior end deflected outwards. The figured specimen differs from typical $\mathrm{Pa}$. lobicornis specimens in the punctuated outer margin.

Age range. Upper Devonian (Famennian); minuta minuta-rhomboidea zones (Spalletta et al., 2017).

\section{Palmatolepis winchelli (Stauffer, 1938)}

Figure $4 \mathrm{~J}$

1938 Bryantodus winchelli n. sp.; Stauffer, p. 423, PI. 48, fig. 33.

1988 Palmatolepis winchelli; Klapper \& Lane, PI. 1, figs. $5-8$.

1993 Palmatolepis winchelli; Klapper \& Foster, p. 24-31, figs. 13.1, 13.2, 18.1-18.8, 18.10, 18.11, 19.619.12, 20.12-20.24.

2015 Palmatolepis winchelli; Mahboubi \& Gatovsky, figs. $4 \mathrm{~N}, 4 \mathrm{O}$.

Material. 18 specimens from samples CP/84 (2), CP/85 (3), CP/86 (1), CP/87a (1), CP/87b (1), CP/89b (6), $\mathrm{CP} / 90$ base (2), CP/91/28-36 (1) and CP/92c/0-9 (1).
Description. Free blade short, corresponding to about $1 / 4$ of the overall length. Inner and outer margins of the platform convex. The posterior end of the platform is subtriangular. The lobe is well-developed, subtriangular and directed laterally. The anterior and posterior sinus are smooth. The azygous node is located at the posterior $1 / 3$ of the element and posteriorly to the lobe. The anterior and posterior carinas are straight, but unaligned. Shallow adcarinal grooves are present on both inner and outer sides of the anterior end of the platform. The surface of the platform is ornamented by small nodes, distributed randomly.

Discussion. This species differs from Palmatolepis triangularis in its slender shape and straight carinas, and from $\mathrm{Pa}$. bogartensis in the narrower lobe.

Age range. Upper Devonian (Frasnian); Upper rhenana-linguiformis zones (Klapper \& Foster, 1993) = FZ12-FZ13 (Klapper \& Kirchgasser, 2016).

Genus Polygnathus Hinde, 1879

Type-species. Polygnathus dubius Hinde, 1879. Givetian-Frasnian; Europe and North America.

Polygnathus cf. eoglaber Ji \& Ziegler, 1993

Figure 4I

1993 Polygnathus eoglaber n. sp.; Ji \& Ziegler, p. 78, PI. 36, figs. 10-15.

Material. one specimen from sample CP/92d.

Description. The free blade is long, aligned with the carina and corresponds to about $1 / 2$ of the whole length. The platform is elliptic, symmetrical in relation to the carina, with the anterior margins highly convex and tapering towards the posterior tip. The platform presents no ornamentation. The carina is made of small conical denticles, almost fused on the anterior half. The element is slightly curved in lateral view, not overcoming the $30^{\circ}$ angle deflection in relation to the free blade. The basal cavity is small, rounded and located on the anterior $1 / 4$ of the platform.

Discussion. This species is characterized by having a drop-shaped platform (wider at the anterior end and rapidly decreasing its width on the posterior end), without ornamentation and deep adcarinal grooves. The shape of the platform and the alignment of the free blade with the carina distinguish it from Polygnathus webbi Stauffer (1938). The existence of a posterior blade also differs it from Polygnathus glaber Ulrich \& Bassler (1926).

Age range. Upper Devonian (Famennian); minuta minuta-gracilis gracilis zones (Spalletta et al., 2017).

Polygnathus webbi Stauffer, 1938

Figure 4F 
1938 Polygnathus webbi n. sp.; Stauffer, p. 439, PI. 53, figs. 25, 26, 28, 29.

1957 Polygnathus webbi; Bischoff \& Ziegler, p. 100, PI. 5, figs. 7-10.

1989 Polygnathus webbi; Wang, PI. 35, figs. 9-10.

1992 Polygnathus webbi; Ji et al., PI. 4, fig. 17.

1992 Polygnathus webbi; Matyja \& Narkiewicz, PI. 1, figs. 8-9.

1993 Polygnathus webbi; Matyja, Pl. 23, fig. 10.

1993 Polygnathus webbi; Ji \& Ziegler, p. 85-86, PI. 34, figs. $1-5$.

2015 Polygnathus webbi; Mahboubi \& Gatovsky, figs. $5 \mathrm{~W}-5 \mathrm{Y}$.

Material. 4 specimens from samples CP/91/28-36 (1), CP/92a/73-88 (1) and CP/92c/0-9 (2).

Description. Free blade corresponding to about $1 / 3$ of the length and straight relative to the carina. Main body is asymmetrical to the carina, with the outer margin wider than the inner one. The inner margin is slightly concave while the outer margin is straight and parallel to the carina on the anterior $1 / 3$ and then highly convex on the remaining $2 / 3$. The width is higher at middle length and also on the anterior end relative to the posterior one, where it ends in a pointed tip. The posterior half of the platform is curved inwards, making an over $20^{\circ}$ angle relative to the free blade. The anterior margins make a straight angle with the carina and are slightly dislocated, being the inner one in a more elevated position. The carina is short, composed of conical denticles, fused together on its whole length and isolated from the rest of the platform by deep adcarinal grooves on the anterior half. Short transverse ridges are present on the margins of the platform. The posterior end is slightly curved downwards in lateral view, making an over $20^{\circ}$ angle with the free blade. The basal cavity is rounded and located on the anterior $1 / 3$ of the platform.

Discussion. This species is characterized by having a very wide and strongly inwardly curved platform at the posterior half. It differs from Polygnathus normalis Miller \& Youngquist (1947) in the slender anterior third and more asymmetrical platform.

Age range. Upper Devonian (Frasnian); Lower falsiovalis-linguiformis zones (Ji \& Ziegler, 1993) = FZ1-FZ13 (Klapper \& Kirchgasser, 2016).

Order PRIONIODONTIDA Dzik, 1976

Family ICRIODONTIDAE Müller \& Müller, 1957

Genus Icriodus Branson \& Mehl, 1938

Type-species. Icriodus expansus Branson \& Mehl, 1938. Givetian-Frasnian; Europe, North America and Morocco.

Icriodus cf. (alternatus) alternatus Branson \& Mehl, 1934

Figure 4B
1934 Icriodus alternatus n. sp.; Branson \& Mehl, p. 225-226, PI. 13, figs. 4-6.

1989 Icriodus alternatus alternatus; Ji, PI. 4, figs. 4-8. 1992 Icriodus alternatus alternatus; Ji et al., PI. 1, figs. 3-4.

1992 Icriodus alternatus alternatus; Matyja \& Narkiewicz, PI. 1, figs. 10-14, PI. 2, figs. 8-15.

1993 Icriodus alternatus alternatus; Matyja, PI. 23, figs. 6-9, PI. 24, figs. 2-3, PI. 25, figs. 1-3.

1993 Icriodus alternatus alternatus; Ji \& Ziegler, p. 55, PI. 5, figs. 5-8.

1995 Icriodus alternatus alternatus; Matyja \& Narkiewicz, PI. 4, fig. 1.

Material. 17 specimens from samples CP/84 (1), CP/92base (2), CP/92a/73-88 (2), CP/92b/140-160 (1), CP/92c/0-9 (3), CP/92d (1), CP/93 (4) and CP/94a (3).

Description. Element long and narrow anteriorly and wide and quadrate posteriorly. Anterior process making a right angle with the inner margin on the anterior side and convex on the posterior side. The upper side of the element presents three rows of tall and individualized teeth. The rows are parallel to each other. The denticles of the middle row are alternated with the ones from the marginal rows. A posterior cusp is aligned with the middle row. Aboral view not figured.

Discussion. The size and shape of the teeth cannot be correctly deduced from the specimens so far, which are characteristics useful for distinguishing Icriodus alternatus from I. symmetricus Branson \& Mehl (1934).

Age range. Upper Devonian (Frasnian-Famennian); Upper rhenana $(\mathrm{Ji}, 1989)=\mathrm{FZ12}$ (Klapper \& Kirchgasser, 2016)-glabra pectinata zones (Spalletta et al., 2017).

\section{RESULTS}

A small amount of residue was retrieved from each sample, meaning that the original rocks had a very high carbonate and/or shale-rich content, as the finer particles are washed out during the processing of the samples.

Most of the larger-grain-size residue was quartz crystals coming from veins within the rock, chalcopyrite, pyritohedric pyrite and/or euhedral dolomite. In samples $\mathrm{CP} / 87 \mathrm{~b}, \mathrm{CP} / 89 \mathrm{a}, \mathrm{CP} / 90$ top and CP/91base, most of the residue was composed of dolomite crystals.

The color of the sediment in each sample differed, ranging from the dark grey in the samples close to the base of the sequence (e.g., CP/84 and CP/85b) to a light brown from the top. Sample CP/94a, presents an orange tone, different from any other sample, given by the clay that it contains. The dark grey color of the conodont specimens indicates a CAl value of $4-5$ (Epstein et al., 1977). 
Several fossil groups were found throughout the sequence (Fig. 2): conodonts, foraminifers, radiolarians, brachiopods, ostracods and crinoids. Sample CP/94b had the highest diversity of fossil groups. For the case of conodonts, a total of 13 species and five different genera (Ancyrodella, Ancyrognathus, Icriodus, Palmatolepis and Polygnathus), were identified (Figs. 2, 4; Tab. 1).

The lowermost sampled bed (Bed 84) yielded specimens of five taxa: Ancyrodella curvata "late" form; Icriodus (alternatus) alternatus; Palmatolepis bogartensis; Pa. boogaardi; and Pa. winchelli. Above this layer, in Bed 85b, Ancyrognathus asymmetricus was recovered. In Bed 91b, the first species of Polygnathus (Po. webbi) was recorded. The last occurrence of $A g$. asymmetricus coincides with the only occurrence of $\mathrm{Ag}$. amana, in sample CP/92a. This bed shows the highest conodont diversity, with eight taxa belonging to all five genera. Ancyrodella curvata "late" form and Pa. bogartensis are present in most samples up to the middle of Bed 92a (sample CP/92b); Pa. boogaardi and Pa. winchelli reach the base of Bed 92b. Icriodus (alternatus) alternatus has a longer range, up to the base of Bed 94a (Fig. 2; Tab. 1). The lowest occurrence of $P$. webbi is in Bed 91b, and it is recorded up to Bed 92b. Consequently, only Icriodus cf. (alternatus) alternatus goes beyond Bed 92b. From Bed 92c upwards, a remarkable change in the conodont taxa is observed, including the extinction of the genus Ancyrodella. This change is associated with an increase in the overall diversity of fossil groups in the immediate beds (92d94b; Fig. 2), then, the diversity of other microfossils decreases.

Above Bed 92b, the conodont record is represented by the common occurrences of $P a$. lobicornis (Beds $92 d-$ 97) and $\mathrm{Pa}$. crepida, which appears slightly higher (Bed 94a) and reaches the highest sample (in Bed 97). In Bed 92d, one specimen of $P$ o. cf. eoglaber was found. In the subsequent level (Bed 93), Pa. cf. subperlobata occurs. Slightly above, two specimens of $\mathrm{Ag}$. sinelaminus were recovered from Bed 94b (Fig. 2; Tab. 1).

\section{DISCUSSION}

The Frasnian stage has been subdivided into 13 conodont biozones named Frasnian Zone (FZ) 1 to FZ 13 , based on studies on the Devonian sequences of Montagne Noire (Klapper, 1989, updated in Klapper \& Kirchgasser, 2016). Ziegler and Sandberg (1990) proposed a different "standard" conodont-based zonation for this stage. Klapper and Becker (1999) presented the first correlation of the 13 zones in the Montagne Noire, also recognized in many localities of USA, Canada, Australia, and the Russian Platform, with the nine "standard" Zones initially recognized in Germany and the Great Basin (USA).

This initial comparison shows that the Upper rhenana and linguiformis zones of Ziegler and Sandberg correlates with the upper part of FZ12 and the whole
FZ13. FZ13 was subsequently subdivided into three parts (FZ13a-C) (Girard et al., 2005). Klapper and Kirchgasser (2016) updated the correlation as follows: jamiae Zone correlates with the lowermost part of FZ11; rhenana Zone extends form the lower part of FZ11 up to the top of FZ13a; the latest Frasnian conodont zone, linguiformis Zone, corresponds to the FZ13b and FZ13c zones.

Ziegler and Sandberg (1990) introduced the standard conodont zonation for the Famennian, synthesizing the previous knowledge. Recently, Spalletta et al. (2017) proposed another conodont-based subdivision for the Famennian, mostly based on the one proposed by Ziegler and Sandberg (1990), where designations of the biozones uses the name of the nominal taxon.

The presence of $\mathrm{Pa}$. boogaardi at the base of the sequence limits the oldest dated stratum (Bed 84) within FZ13a to FZ13c. After Klapper and Kirchgasser (2016, fig. 5), FZ13 correlates to the uppermost part of the rhenana Zone (FZ13a) and the linguiformis Zone (FZ13b-C). Palmatolepis bogartensis, Pa. winchelli, Ancyrodella curvata, and I. cf. (alternatus) alternatus are consistent with this age. These taxa appear earlier and continue to the top of the Frasnian, except $I$. (alternatus) alternatus that ranges into the Famennian. The record of $\mathrm{Ag}$. asymmetricus in Bed 85a is also congruent; it first appears earlier in the upper part of FZ12 Zone and becomes extinct at the end of the Frasnian (Klapper, 1990, 1997; Over, 1997). Polygnathus webbi is a long-ranging taxon that disappears at the end of the Frasnian (Klapper, 1997).

The record of Ancyrognathus amana from the middle of Bed 92a is an important datum. According to Klapper (1990) this taxon is restricted to the FZ13 Zone and does not reach the top of the Frasnian. Subsequently, Klapper (1997) established its uppermost range at CSU 130.5 (from his Frasnian Composite Standard), which according to the threefold subdivision of the FZ13 Zone, corresponds to the FZ13b Zone, and not the top. The base of FZ13C is placed at CSU 131.3 (Klapper \& Kirchgasser, 2016). Consequently, this part of Bed 92a lies below the top of the Frasnian. Records of $P a$. winchelli, $P a$. boogaardi, and $P$. webbi at the base of Bed 92b indicate a Frasnian age for this level.

The next record in Bed 92d corresponds to a Famennian association (see below). Thus, the Frasnian-Famennian boundary is in the narrow interval of about $45 \mathrm{~cm}$ between the base of Bed 92b and Bed 92d.

Bed 92d yielded Pa. lobicornis and Po. cf. eoglaber. Both species do not occur below the base of the minuta minuta Zone (Spalletta et al., 2017). Bed 93b records $P a$. cf. subperlobata, which appears earlier in the subperlobata Zone, but has a long range, reaching the marginifera marginifera Zone. The first occurrence of $P a$. crepida, which names the crepida Zone, is in Bed 94a. Finally, Ag. sinelaminus was recorded in Bed 94b. These taxa, as an association, range within the crepida, termini, glabra prima, and glabra pectinata zones, where $\mathrm{Pa}$. Iobicornis and $\mathrm{Pa}$. crepida can reach the 
rhomboidea Zone. However, the association found in Beds $92 d$ and 93 is consistent with the minuta minuta Zone, which precedes the crepida Zone.

Liao and Valenzuela-Ríos (2017) recorded Pa. termini above Bed 97 , and because this species only occurs in the termini to glabra prima zones, the base of Bed 97 cannot be higher than the glabra prima Zone. As no species with a first appearance datum in the termini or glabra prima zones were found in the sequence, the presence of any of these zones cannot be confirmed. Thus, the most probable Famennian zonation of this sequence starts with the minuta minuta Zone, from Beds $92 \mathrm{~d}$ and 93 , and is followed by the crepida Zone, from Beds 94 to 97 .

Based on these data, the Frasnian-Famennian boundary is located between beds $92 \mathrm{~b}$ (Frasnian) and 92d (Famennian). This implies that, in the CP section, the three basal Famennian subperlobata, triangularis and delicatula platys zones must be represented in the thin stratigraphical interval of $45 \mathrm{~cm}$ between these two samples, or missing, which is common in other locations (e.g., Appalachian-Illinois basins in the USA; Over, 2002).

The apparent absence of the subperlobata to delicatula platys zones, which precede the minuta minuta Zone in the Lower Famennian, combined with the lack of any evidence of a stratigraphical hiatus in the studied interval, suggest that those basal Famennian zones are highly condensed in the upper half of Bed $92 \mathrm{~b}$ and Bed 92c.

The conodont sequence indicates a marked change in composition between those two samples. The genus Ancyrodella became extinct; the Palmatolepis and Ancyrognathus faunas change. Both the extinction of Ancyrodella and the replacement of the two other genera are also observed everywhere, and serve to separate Frasnian and Famennian strata.

In addition to the biostratigraphical data, the dark grey color (CAI $=4-5)$ of the conodont specimens retrieved from the samples suggests the maximum temperature of metamorphism exceeded $200^{\circ} \mathrm{C}$ and possibly reached $300^{\circ} \mathrm{C}$, based on the calculations of Epstein et al. (1977), when considering a 100-million-year gap for the thermal event (Alpine orogeny). The presence of dolomite crystals, in small amounts and only in some of the samples, is in agreement with those results, although similar results can be achieved at lower temperature ranges.

Furthermore, the existence of chalcopyrite and pyritohedric pyrite in reasonable quantities in the picked residues suggest a good fluid circulation within the formation and a sulphur-rich composition of that fluid (Alonso-Azcárate et al., 2001; Craig et al., 1998), possibly influenced by the deformation and metamorphism of the region.

\section{CONCLUSIONS}

The upper part of the Comabella Formation in Compte is rich in microfossil remains, especially conodonts. Conodonts that document the uppermost Frasnian FZ13 are recorded in the lower 8 meters. This association is composed of Ancyrodella curvata "late" form, Ancyrognathus asymmetricus, Ag. amana, Icriodus cf. (alternatus) alternatus, Palmatolepis bogartensis, $\mathrm{Pa}$. boogaardi, $\mathrm{Pa}$. winchelli, and Polygnathus webbi.

The Frasnian-Famennian boundary was resolved to a $45 \mathrm{~cm}$ interval between the samples from beds 92b and 92d. Records below and above these samples show a marked change in the composition of conodont faunas: the genus Ancyrodella disappears and the representatives of the genera Palmatolepis, Polygnathus, and Ancyrognathus change.

The first Famennian conodont zone documented in the $\mathrm{CP}$ section is the minuta minuta Zone, represented by Beds 92d and 93, followed by the crepida Zone, which represents the uppermost $2.5 \mathrm{~m}$ of the sequence. The lack of any demonstrable hiatus in this part of the sequence suggest that a strong condensation happens at the beginning of the Famennian in Compte.

Supplementary information. The article has no additional data.

Author contributions. Conception of the work: J.I.V.-R and J.-C.L.; sampling: G.S., J.I.V.-R and J.-C.L.; Lab work: G.S.; data analysis and interpretation: G.S., J.I.V.-R and J.-C.L.; G.S. drafted the article with critical revision of J.I.V.-R and J.-C.L. All authors approved the final version of the manuscript and agree to be held accountable for the content therein.

Competing interests. The authors declare that they have no known competing financial interests or personal relationships that could have appeared to influence the work reported in this paper.

Funding. Gonçalo Silvério was funded by Sociedad Española de Paleontología (ref. AJISEP-2019-07151) and the Fundação para a Ciência e Tecnologia (ref. 2020.08450.BD).

Author details. Gonçalo Silvério', José I. Valenzuela-Ríos ${ }^{2}$ \& Jau-Chyn Liao². 'Instituto de Ciências da Terra, Pólo de Évora, Rua Romão Ramalho, 59, 7002-554 Évora, Portugal; 2Department of Botany and Geology, Universidad de Valencia, C/Dr. Moliner 50, E-46100 Burjassot, Spain; gsilverio@ uevora.pt; jose.i.valenzuela@uv.es; jau.liao@uv.es

Ackowledgements. The authors thank Dr. Jeffrey Over and Dr. Carlos Martínez-Pérez for reviewing this paper. This study represents a contribution to the Project IGCP-652, of UNESCO. It also represents a contribution to the University of Valencia Research Group GIUV2017-395. We thank the support of the Microscopy section of the Support Research Center, University of Valencia. Prof. Gilbert Klapper aided in the determination of the critical specimens bracketing the F/F interval when one of us (JIV-R) visited him at University of lowa in 1991. 


\section{REFERENCES}

Alonso-Azcárate, J., Rodas, M., Fernández-Díaz, L., Bottrell, S. H., Mas, J. R., \& López-Andrés, S. (2001). Causes of variation in crystal morphology in metamorphogenic pyrite deposits of the Cameros Basin (N Spain). Geological Journal, 36(2), 159-170. doi: 10.1002/gj.889

Bischoff, G., \& Ziegler, W. (1957). Das Alter der "Urfer Schishten" im Marburger Hinterland nach Conodonten. Notizblatt des Hessisches Landesamt fur Bodenforschung, 84, 138-169.

Boersma, K. T. (1973). Devonian and Lower Carboniferous conodont biostratigraphy, Spanish Central Pyrenees. Leidse Geologische Mededelingen, 49(2), 303-377.

Branson, E. B., \& Mehl, M. G. (1934). Conodonts from the Grassy Creek shale of Missouri. Missouri University Studies, 8, 171-259.

Branson, E. B., \& Mehl, M. G. (1938). The conodont genus Icriodus and its stratigraphic distribution. Journal of Paleontology, 12(2), 156-166. https://www.jstor.org/ stable/1298727

Craig, J. R., Vokes, F. M., \& Solberg, T. N. (1998). Pyrite: physical and chemical textures. Mineralium Deposita, 34, 82-101. doi: 10.1007/s001260050187

Dzik, J. (1976). Remarks on the evolution of Ordovician conodonts. Acta Palaeontologica Polonica, 21(4), 395459.

Epstein, A. G., Epstein, J. B., \& Harris, L. D. (1977). Conodont color alteration - an index to organic metamorphism. Geological Survey Professional Paper, 995, 1-27.

Girard, C., Klapper, G., \& Feist, R. (2005). Subdivision of the terminal Frasnian linguiformis conodont Zone, revision of the correlative interval of Montagne Noire Zone 13, and discussion of stratigraphically significant associated trilobites. In D. J. Over, J. R. Morrow \& P. B. Wignall (Eds.), Understanding Late Devonian and Permian-Triassic Biotic and Climatic Events: Towards an Integrated Approach (pp. 181-198). Elsevier. doi: 10.1016/S0920-5446(05)80007-X

Glenister, B. F., \& Klapper, G. (1966). Upper Devonian Conodonts from the Canning Basin, Western Australia. Journal of Paleontology, 40(4), 777-842. https://www. jstor.org/stable/1301879

Gouwy, S., Liao, J.-C., \& Valenzuela-Ríos, J. I. (2016). Graphic correlation of the upper Eifelian to lower Frasnian (Middle-Upper Devonian) conodont sequences in the Spanish Central Pyrenees and comparison with composite standards from other areas. Palaeontologia Electronica, 19.3.40A, 1-18. doi: 10.26879/669

Haeckel, E. (1874). Anthropogenie oder entwicklungsgeschichte des menschen. Gemeinverständliche wissenschaftliche vorträge über die grundzüge der menschlichen keimes-und stammes - geschichte. Wilhelm Engelmann.

Hass, W. H. (1959). Conodonts from the Chappel Limestone of Texas. U.S. Geological Survey Professional Paper, 294, 365-399. doi: 10.3133/pp294J

Helms, J. (1963). Zur "Phylogenese" und Taxionomie von Palmatolepis (Conodonta, Oberdevon). Geologie, 12(4), 449-485.

Hinde, G. J. (1879). On conodonts from the Chazy and Cincinnati Group of the Cambro-Silurian, and from the Hamilton and Genesee-Shale divisions of the Devonian, in Canada and the United States. Geological Society of
London, Quarterly Journal, 35, 351-369. doi: 10.1144/ GSL.JGS.1879.035.01-04.23

Institut Cartogràfic i Geològic de Catalunya (2021). Mapa Geològic de Catalunya 1:25 000. Link: https://betaportal. icgc.cat/visor/client_utfgrid_geo.html

Ji, Q. (1989). On the Frasnian Conodont Biostratigraphy in the Guilin Area of Guangxi, South China. Courier Forschungs-Institut Senckenberg, 117, 303-319.

Ji, Q., \& Ziegler, W. (1993). The Lali section: an excellent reference section for Late Devonian in south China. Courier Forschungs-Institut Senckenberg, 157, 1-183.

Ji, Q., Ziegler, W., \& Dong, X. (1992). Middle and Late Devonian conodonts from the Licum section Youngfu, Guangxi, South China. Courier Forschungs-Institut Senckenberg, 154, 85-105.

Klapper, G. (1989). The Montagne Noire Frasnian (Upper Devonian) conodont succession. In N. J. McMillan, A. F. Embry, \& D. J. Glass (Eds.), Devonian of the World. Paleontology, Paleoecology, Biostratigraphy). Canadian Society of Petroleum Geologists, Memoir, 14(3), 449468.

Klapper, G. (1990). Frasnian species of the Late Devonian conodont genus Ancyrognathus. Journal of Paleontology, 64(6), 998-1025. https://www.jstor.org/stable/1305740

Klapper, G. (1997). Graphic correlation of Frasnian (Upper Devonian) sequences in Montagne Noire, France, and western Canada. Geological Society of America, Special Paper, 321, 113-129.

Klapper, G., \& Foster, C. T. (1993). Shape analysis of Frasnian species of the Late Devonian conodont genus Palmatolepis. Memoir (The Paleontological Society), 32, 1-35. doi: 10.1017/S0022336000062168

Klapper, G., \& Becker, R. T. (1999). Comparison of Frasnian (Upper Devonian) Conodont Zonations. Bollettino della Società Paleontologica Italiana, 37(2-3), 339-348.

Klapper, G., \& Kirchgasser, W. (2016). Frasnian Late Devonian conodont biostratigraphy in New York: graphic correlation and taxonomy. Journal of Paleontology, 90(3), 525-554. doi: 10.1017/jpa.2015.70

Klapper, G., \& Lane, H. R. (1988). Frasnian (Upper Devonian) conodont sequence at Luscar Mountain and Mount Haultain, Alberta Rocky Mountains. Devonian of the World: Proceedings of the 2nd International Symposium on the Devonian System - Memoir 14, Volume III: Paleontology, Paleoecology and Biostratigraphy (pp. 469-478). Calgary.

Klapper, G., Lindström, M., Sweet, W. C., \& Ziegler, W. (1981). Catalogue of Conodonts. Volume IV. E. Schweizerbart'sche Verlagsbuchhandlung.

Klapper, G., Uyeno, T. T., Armstrong, D. K., \& Telford, P. G. (2004). Conodonts of the Williams Island and Long Rapids Formations (Upper Devonian, FrasnianFamennian) of the Onakawana B Drillhole, Moose River Basin, Northern Ontario, with a revision of lower Famennian Species. Journal of Paleontology, 78(2), 371-387. doi: 10.1666/0022-3360(2004)078<0371: COTWIA> 2.0.CO;2

Lamarck, J. B. (1802). Systême des animaux vertèbres, ou Tableau général des classes, des ordres et des genres de ces animaux; Présentant leurs caractères essentiels et leur distribution, d'après la considération de leurs rapports naturels et leur organisation, et suivant l'arrangement établis dans les galeries du Muséum d'Histoire Naturelle, parmi leur dépouilles conservées; Précédé du discours d'ouverture du cours de zoologie, 
donné dans le Muséum National d'Histoire Naturelle l'an 8 de la République. Institut National de France.

Liao, J.-C. (2014). Bioestratigrafía con conodontos del givetiense (Devónico Medio) del Pirineo Central. (PhD thesis, Universidad Complutense de Madrid).

Liao, J.-C., \& Valenzuela-Ríos, J. I. (2008). Givetian and early Frasnian conodonts from the Compte section (MiddleUpper Devonian, Spanish Central Pyrenees). Geological Quaterly, 52(1), 1-18.

Liao, J.-C., \& Valenzuela-Ríos, J. I. (2017). Givetian to Famennian conodonts (Middle-Upper Devonian) at CP section. In T. J. Suttner, J. I. Valenzuela-Ríos, J.-C. Liao, C. Corradini, \& L. Slavík (Eds.), International Conodont Symposium 4. Progress on Conodont investigation. (pp. 99-105). Valencia.

Mahboubi, A., \& Gatovsky, Y. (2015). Late Devonian conodonts and event stratigraphy in northwestern Algerian Sahara. Journal of African Earth Sciences, 101, 322-332. doi: 10.1016/j.jafrearsci.2014.10.004

Martínez-Pérez, C. (2010a). Conodontos del Emsiense (Devónico Inferior) del Pirineo Central Español. (PhD thesis, Universitat de València).

Martínez-Pérez, C. (2010b). Icriodus riosi, nueva especie de conodonto en el Devónico Inferior del Pirineo Central español. Revista Española de Paleontología, 25(2), 139-147. doi: 10.7203/sjp.25.2.19014

Martínez-Pérez, C., \& Valenzuela-Ríos, J. I. (2014). New Lower Devonian Polygnathids (Conodonta) from the Spanish Central Pyrenees, with comments on the early radiation of the group. Journal of Iberian Geology, 40(1), 141-155. doi: 10.5209/rev_JIGE.2014.v40.n1.44095

Martínez-Pérez, C., Valenzuela-Ríos, J. I., Navas-Parejo, P., Liao, J.-C., \& Botella, H. (2011). Emsian (Lower Devonian) Polygnathid (Conodont) succession in the Spanish Central Pyrenees. Journal of Iberian Geology, 37(1), 45-64. doi: 10.5209/rev_JIGE.2011.v37.n1.4

Matyja, H. (1993). Upper Devonian of Western Pomerania. Acta Geologica Polonica, 43(1-2), 27-94.

Matyja, H., \& Narkiewicz, M. (1992). Conodont Biofacies Succession near the Frasnian/Famennian boundary. Some Polish Examples. Courier Forschungs-Institut Senckenberg, 154, 125-147.

Matyja, H., \& Narkiewicz, M. (1995). Conodont stratigraphy of the Upper Devonian in the Jjanczyce I borehole section, eastern Holy Cross Mts. Geological Quaterly, 39(2), 177-206.

Metzger, R. A. (1994). Multielement reconstructions of Palmatolepis and Polygnathus (Upper Devonian, Famennian) from the Canning Basin, Australia, and Bactrian Mountain, Nevada. Journal of Paleontology, 68(3), 617-647. doi: 10.1017/S0022336000025956

Mey, P. H. W. (1967). The geology of the upper Ribagorzana and Baliera valleys, Central Pyrenees, Spain. Leidse Geologische Mededelingen, 41, 153-220.

Miller, A. K., \& Youngquist, W. (1947). Conodonts from the Type Section of the Sweetland Creek Shale in lowa. Journal of Paleontology, 21(6), 501-517. https://www. jstor.org/stable/1299223

Müller, K. J., \& Müller, E. M. (1957). Early Upper Devonian (Independence) Conodonts from lowa, Part I. Journal of Paleontology, 31(6), 1069-1108. https://www.jstor.org/ stable/1300497

Muñoz, J. A. (1992). Evolution of a continental collision belt: ECORS-Pyrenees crustal balanced cross-section. In K. McClay (Ed.), Thrust tectonics (p 235-246). Editorial Chapman \& Hall. doi: 10.1007/978-94-011-3066-0_21
Over, D. J. (1997). Conodont biostratigraphy of the Java Formation (Upper Devonian) and the Frasnian-Famennian boundary in western New York State. Geological Society of America, Special Paper, 321, 161-177.

Over, D. J. (2002). The Frasnian/Famennian boundary in central and eastern United States. Palaeogeography, Palaeoclimatology, Palaeoecology, 181, 153-169. doi: 10.1016/S0031-0182(01)00477-1

Over, D. J. (2007). Conodont biostratigraphy of the Chattanooga Shale, Middle and Upper Devonian, southern Appalachian Basin, eastern United States. Journal of Paleontology, 81(6), 1194-1217. doi: 10.1666/ 06-056R.1

Pander, C. H. (1856). Monographie der fossilen Fische des silurischen Systems des russisch-baltischen Gouvernements. Buchdruck aus der K. Akademie der Wissenschaften, 1, 1-91.

Sannemann, D. (1955). Oberdevonische Cconodonten (to II). Senckenbergiana lethaea, 36, 123-156.

Schülke, I. (1995). Evolutive Prozesse bei Palmatolepis in der frühen Famenne-Srufe (Conodonta, Ober-Devon). Göttinger Arbeiten zur Geologie und Paläontologie, 67, $1-108$.

Schülke, I. (1999). Early Famennian conodont biostratigraphy of the stratotype area (Montagne Noire, Southern France). Bollettino della Società Paleontologica Italiana, 37(2-3), 375-391.

Slavík, L., Valenzuela-Ríos, J. I., Hladil, J., Chadimová, L., Liao, J.-C., Hušková, A., Calvo, H., \& Hrstka, T. (2016). Warming or cooling in the Pragian? Sedimentary record and petrophysical logs across the LochkovianPragian boundary in the Spanish Central Pyrenees. Palaeogeography, Palaeoclimatology, Palaeoecology, 449, 300-320. doi: 10.1016/j.palaeo.2016.02.018

Spalletta, C., Perri, M. C., Over, D. J., \& Corradini, C. (2017). Famennian (Upper Devonian) conodont zonation: revised global standard. Bulletin of Geosciences, 92(10), 31-57.

Stauffer, C. R. (1938). Conodonts of the Olentangy shale. Journal of Paleontology, 12(5), 411-443. https://www. jstor.org/stable/1298661

Ulrich, E. O., \& Bassler, R. S. (1926). A classification of the tooth-like fossils, conodonts, with descriptions of American Devonian and Mississipian species. Proceedings of the United States National Museum, 68, $1-63$.

Valenzuela-Ríos, J. I., \& Liao, J.-C. (2006). Annotations to Devonian Correlation Table, R 357-360 di-ds 06: Spanish Central Pyrenees, southern part. Senckenbergiana lethaea, 86(1), 105-107.

Valenzuela-Ríos, J. I., \& Liao, J.-C. (2012). Color/facies changes and Global Events, a hoax? A case study from the Lochkovian (Lower Devonian) in the Spanish Central Pyrenees. Palaeogeography, Palaeoclimatology, Palaeoecology, 367-368, 219-230. doi: 10.1016/j. palaeo.2011.09.007

Valenzuela-Ríos, J. I., Liao, J.-C., Martínez-Pérez, C., Castelló, V., \& Botella, H. (2005). Datos preliminares sobre los conodontos y restos de peces del Lochkoviense (Devónico Inferior) de Compte-I (Valle del Noguera Pallaresa, Pirineos). In J. A. Gámez, E. Liñán, \& J. I. Valenzuela-Ríos (Eds.), Memorias de las VIII Jornadas Aragonesas de Paleontología: "La cooperación linternacional en la Paleontología española. Homenaje al Profesor Peter Carls" (pp. 131-145). Zaragoza. 
Valenzuela-Ríos, J. I., Slavík, L., Liao, J.-C., Calvo, H., Hušková, A., \& Chadimová, L. (2015). The middle and upper Lochkovian (Lower Devonian) conodont successions in key peri-Gondwana localities (Spanish Central Pyrenees and Prague Synform) and their relevance for global correlations. Terra Nova, 27, 409415. doi: 10.1111/ter.12172

Valenzuela-Ríos, J. I., Liao, J.-C., \& Martínez-Pérez, C. (2017). The Devonian in the Compte sections. International Conodont Symposium 4 (pp. 89-91). Valencia.

Wang, C.-Y. (1989). Devonian conodonts of Guangxi. Memoirs of Nanjing Institute of Geology and Palaeontology, Academia Sinica, 25, 1-152.
Ziegler, W. (1959). Conodonten aus Devon und Karbon Südwesteuropas und Bemerkungen zur bretonischen Faltung (Montagne Noire, Massiv Mounthoumet, Span. Pyrenäen). Neus Jahrbuch für Geologie und Paläeontologie, Monatshefte, 7, 289-309.

Ziegler, W., \& Wang, C.-Y. (1985). Sihongshan section, a regional reference section for the Lower-Middle and Middle-Upper Devonian boundaries in East Asia. Courier Forschungsinstitut Senckenberg, 75, 17-38.

Ziegler, W., \& Sandberg, C. A. (1990). The Late Devonian standard conodont zonation. Courier Forschungsinstitut Senckenberg, 121, 1-115. 
